\title{
AKTIVITAS SITOTOKSIK DARI EKSTRAK BINTANG ULAR (Ophiomastix annulosa) TERHADAP PERKEMBANGAN AWAL EMBRIO BULU BABI (Tripneustes gratilla).
}

\section{(The Cytotoxic Activity Of Extracts Brittle Star (Ophiomastix annulosa) On The Development Of Sea Urchin Embryos (Tripneustes gratilla)}

\author{
Remy E.P. Mangindaan ${ }^{1^{*}}$ dan Margareth S. P. Lesnussa ${ }^{2}$ \\ ${ }^{1}$ Program Studi IImu Kelautan, Fakultas Perikanan dan Ilmu Kelautan, Universitas Sam \\ Ratulangi, Manado \\ 2 Dinas Kelautan dan Perikanan Halmahera Utara \\ *e-mail : remysang @yahoo.com
}

The research in marine natural product chemistry has been coming along by the discovery of many active substances, such as cytotoxic substance, antimicrobial, antifungi, and so forth. Among the active substances, cytotoxic is one of the active substance which already been found in many organisms with the exception in Brittle star (Ophomastix annulosa). As of today, only a few compounds have been isolated from this organism and thus, it could be a potential source of cytotoxic substance. The aim of the research was to obtain the extract of $O$. annulosa and to detect the cytotoxic activity of brittle star $O$. annulosa extracts on the development of sea urchin embryos and sea urchin eggs. The specimen was extracted with methanol solvent and fractionated with organic solvents; ethyl acetate, chloroform and hexane to yield three fractions. The methanolic extract and all fractions were tested against the development of sea urchin embryos and sea urchin eggs. The result showed that extracts of $O$. annulosa contain cytotoxic substance, base on the data of methanolic extract and three fractions, ethyl acetate, hexane and chloroform. Among the three fractions, chloroform exhibit the most powerfull cytotoxic activity and therefore need to be purified to obtain pure compounds.

Keywords: Cytotoxic, Ophomastix annulosa, Fraction, Substance, Activity

Penelitian di bidang alam bahari telah berkembang ditandai dengan ditemukannya substansi-substansi seperti sitotoksik, antimikroba, antifungi dan sebagainya yang dibutuhkan dalam penyediaan bahan-bahan farmasi. Penelitian ini bertujuan untuk mendeteksi ada tidaknya substansi sititoksik pada bintang ular Ophimastix annulosa dan menelusuri keberadaan senyawanya. Sampel diekstraksi dengan pelarut metanol, kemudian dipartisi menggunakan pelarut etil asetat, heksan dan kloroform. Tiap fraksi diuji pada sel telur bulu babi (Tripneustes gratilla) sebelum dan sesudah difertilisasi. Hasil pengamatan menunjukkan bahwa ekstrak metanolik $O$. annulosa dan ketiga fraksi (etil asetat, heksan dan kloroform) memiliki substans sitotoksik. keempat fraksi yang diuji mampu menghambat perkembangan sel telur dan embrio bulu babi. fraksi kloroform menunjukkan aktivitas sitotoksik tertinggi dibandingkan ketiga fraksi lainnya sehingga perlu dilakukan pemurnian lanjut untuk menemukan senyawa murni.

Kata Kunci : Sitotoksik, Ophomastix annulosa, fraksi, Substans, Aktivitas

\section{PENDAHULUAN}

Pemanfaatan produk alam bahari di bidang kesehatan dewasa ini makin berkembang dengan didapatkan substansi bioaktif meliputi: antimikroba, larvasida, antikoagulan dan sitotoksik sebagai sumber bahan obat yang dapat mengatasi berbagai penyakit. Faulkner (1992) menyatakan bahwa sitotoksik mampu menghambat pertumbuhan sel kanker secara efektif. Siswandono (1995 Shier; 1988
Rahman (2001), obat antikanker yang ideal akan membunuh sel kanker tanpa mempengaruhi jaringan normal.

Laut memiliki keragaman biota yang berpotensi sebagai sumber senyawa antitumor, di antaranya yaitu echinodermata yang diindikasikan mengandung senyawa berkhasiat. Dari golongan Echinodermata khususnya pada kelas bintang ular (Ophiuroidea), Faulkner (1995) berhasil mengisolasi senyawa sitotoksik bintang ular Ophioderma longicaudum. 
(Grzimek, 1972), Ophiomastix annulosa merupakan salah satu jenis bintang ular dengan lengan panjang dan ramping. Bintang ular umumnya mengandung senyawa golongan steroid (D'Auria et al,1993; Faulkner 1994). Fusetani (1999 dan Iwamoto 2001), melaporkan bahwa senyawa sitotoksik yang diisolasi dari sponge dan alga mampu menghambat pertumbuhan sel leukemia. Dua jenis sponge genus Stylotella agminata dan $S$. aurantium berpotensi sitotoksik terhadap beberapa sel kanker dengan $\mathrm{IC}_{50}$ 0,1-10ug/mL (Faturoso et al, 2012).

Biota laut asal perairan Sulawesi Utara perlu diteliti lebih seksama untuk memperoleh substans bioaktif dan senyawa-senyawa penting dalam bidang farmasi. Dari beberapa jenis sponge asal perairan Manado berhasil diisolasi senyawa Spironaamidine (Nagasawa dkk, 2011); Salsolinol (Nagasawa dkk, 2011); Hyrtioreticulins A-E (Yamanokuchi, dkk, 2012).

Embrio bulu babi nampak transparan sehingga sel-sel dapat diamati dengan jelas di mikroskop dan juga memiliki pola pembelahan yang sederhana dapat digunakan untuk memantau lingkungan dan indikator kualitas air. Menurut (Alex \& Kyle, 1998 dan Shokita dkk 1991)

Adapun tujuan penelitian yaitu: mendeteksi ada tidaknya kandungan substansi sitotoksik dan menelusuri komponen aktif sitotoksik yang terkandung pada bintang ular $O$. annulosa pada berbagai fraksi larut terhadap perkembangan awal embrio bulu babi (Tripneustes gratilla).

\section{METODE PENELITIAN}

\section{Tempat dan Waktu Penelitian}

Penelitian dilakukan pada
September - Oktober 2012.
Pengambilan sampel bintang ular
Ophiomastix annulosa dilakukan di
perairan Bulo, Kecamatan Tombariri,
Kabupaten Minahasa. Pengambilan
bulu babi di perairan Tongkeina,
Kecamatan Bunaken Kotamadya
Manado. Ekstraksi dan pengujian
aktivitas sitotoksik bintang ular

dilakukan di Laboratorium Kimia Bahan Hayati Laut, Fakultas Perikanan dan IImu Kelautan UNSRAT.

\section{Ekstraksi Bintang Ular}

Sampel bintang ular O. Annulosa yang diperoleh dipotong-potong lalu dimaserasi dalam metanol $(1: 2) \mathrm{w} / \mathrm{v}$ selama 24 jam, setelah dekantasi, debris dimaserasi kembali sebanyak 2 kali. Keseluruhan ekstrak difiltrasi dan dievaporasi menggunakan rotary vaccum evaporator sehingga diperoleh ekstrak metanolik.. Selanjutnya ekstrak metanolik bintang ular dipartisi dengan berbagai pelarut (etil asetat, heksan dan kloroform). Setiap fraksi yang diperoleh dikeringkan melalui freeze dryer

\section{Pengujian Sitotoksik}

Pengujian sitotoksik, menggunakan gonad bulu babi Tripneustes gratilla jantan dan betina yang telah matang. Fertilisasi buatan dilakukan berdasarkan metode Tyler (1949) dalam Chizak (1975) yang dimodifikasi.

\section{a. Pengujian pada Sel Telur (Sebelum Fertilisasi)}

Adapun pengujian dilakukan dengan cara: beberapa tetes suspensi sel telur dimasukkan kedalam cawan petri yang mengandung ekstrak setiap perlakuan konsentrasi 20 ppm lalu didiamkan selama 1 jam kemudian dibilas, lalu ditetesi suspensi sperma. Setelah terbentuk membran fertilisasi, suspensi sel telur dibilas lagi.

\section{b. Pengujian pada Embrio (Setelah Fertilisasi)}

Fertilisasi dilakukan dengan menggabungkan sel telur dan sel sperma lalu diinkubasi selama 30 menit. Setelah terbentuk terjadi fertilisasi, suspensi sel telur dan sperma dimasukkan ke dalam tiap cawan petri yang mengandung ekstrak setiap perlakuan konsentrasi 20 ppm.

\section{Pengamatan Perkembangan Awal Embrio Bulu Babi}

Perkembangan awal embrio dilakukan 8 kali yaitu pada: 0,5 jam; 1 
jam; 2 jam; 3 jam; 6 jam;12 jam; 24 jam; dan 48 jam di bawah mikroskop dengan pembesaran 100x Pembelahan bulu babi yang diamati yaitu perkembangan awal embrio pada tahapan membran fertilisasi, tahap pembelahan 2 sel, 4 sel, 8 sel, hatching, blastula, gastrula, prisma dan pluteus pada tiap perlakuan. Hal yang sama juga dilakukan pada kontrol.

\section{HASIL DAN PEMBAHASAN}

\section{Perkembangan Awal Embrio Bulu babi}

Hasil pengamatan terhadap fertilisasi buatan yang telah dilakukan menunjukkan bahwa fertilisasi buatan ini telah berlangsung dengan baik, karena seluruh sel telur difertilisasi oleh sel sperma. Hal ini berarti bulu babi Tripneustes gratilla yang digunakan untuk fertilisasi buatan telah matang gonad.

\section{Aktivitas Sitotoksik Sel Telur Bulu Babi Untuk Perlakuan Pada Ekstrak Metanolik, Fraksi Larut Etil Asetat, Heksan dan Kloroform.}

Berdasarkan

pengamatan

(Gambar 1) yang dilakukan selama 48 jam ternyata bahwa keempat fraksi menunjukkan penghambatan perkembangan sel telur (bersifat sitotoksik), dengan aktivitas penghambatan yang berbeda. Fraksi larut kloroform aktivitas penghambatannya tertinggi dan persentasi jumlah sel telur yang tidak mengalami fertilisasi hampir 97\%. Fraksi larut etil asetat dan heksan menunjukkan aktivitas yang tidak jauh berbeda, sedangkan ekstrak metanolik aktivitasnya terendah.

\section{Aktivitas Sitotoksik Pada Embrio Bulu Babi pada setiap Perlakuan (Ekstrak Metanolik, Fraksi Larut Etil Asetat, Heksan dan Kloroform).}

Perlakuan pada embrio bulu babi (Gambar 2) ternyata fraksi larut etil asetat, heksan, kloroform dan ekstrak metanolik memiliki aktivitas sitotoksik dengan tingkat penghambatan yang berbeda-beda. Dari keempat fraksi yang diujikan ternyata ekstrak metanolik memiliki aktivitas penghambatan terendah dan perkembangan embrio bulu babi membutuhkan waktu yang lebih lama. Hal ini diduga karena substansi toksin yang terkandung dalam ekstrak metanolik belum cukup mampu untuk menghambat perkembangan awal embrio bulu.

Fraksi kloroform memiliki aktivitas sitotoksik tertinggi dan mampu menghentikan perkembangan awal embrio bulu babi pada tahapan membran fertilisasi. Hal ini mengindikasikan bahwa senyawasenyawa yang terkandung dalam fraksi kloroformdapat digunakan untuk mematikan sel tumor atau menghentikan perkembangannya pada konsentrasi yang rendah, aktivitas kloroform mampu menghentikan perkembangan sel sejak 0,5 jam pertama hingga 48 jam terhadap sel telur maupun embrio dan ini berarti bahwa substansi sitotoksik sebagian besar terkandung dalam fraksi larut kloroform.

Kloroform termasuk pelarut yang bersifat semi polar dengan index polaritas 4,1 (Przybytek, 1984), sehingga senyawa-senyawa yang terkandung pada fraksi larut kloroform adalah senyawa-senyawa yang bersifat semi polar. Diduga senyawa yang terlarut dalam fraksi ini adalah senyawa steroid dari golongan lipida. Ville $d k k$., (1984) menjelaskan bahwa lipida atau lemak merupakan kelompok senyawa yang dapat larut dalam kloroform, eter atau benzena tetapi hanya sedikit larut dalam air. Salah satu senyawa lipida yaitu steroid diketahui dimiliki oleh bintang ular $O$. Annulosa seperti yang telah dikemukakan oleh D'Auria et all (1993) dan Faulkner (1994). Aktivitas sitotoksik berikutnya dimiliki oleh fraksi larut etil asetat dengan indeks polaritas 4,4 mampu menarik senyawa-senyawa yang bersifat non polar dan semi polar, sedangkan fraksi larut heksan dengan indeks polaritas 0,1 mampu menarik senyawa-senyawa yang bersifat non polar memiliki aktivitas terendah dibandingkan dengan ekstrak metanolik 


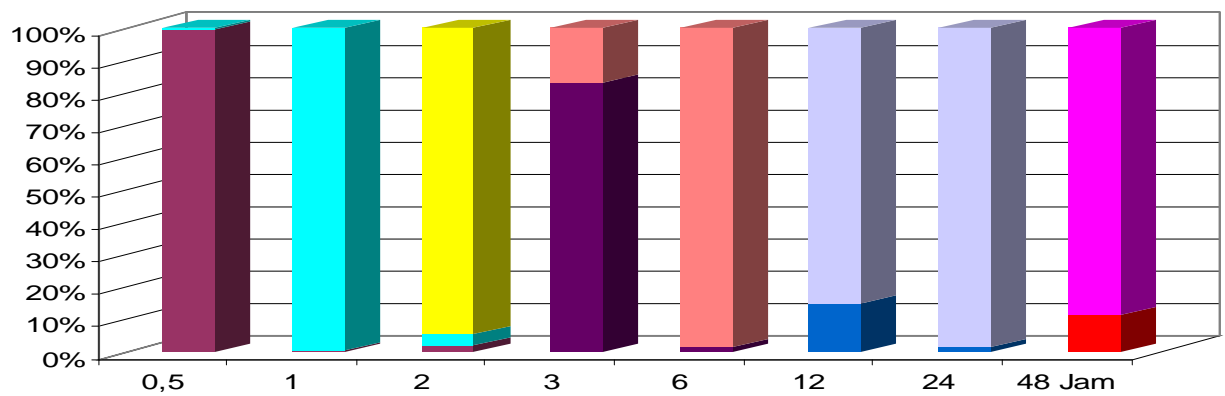

A

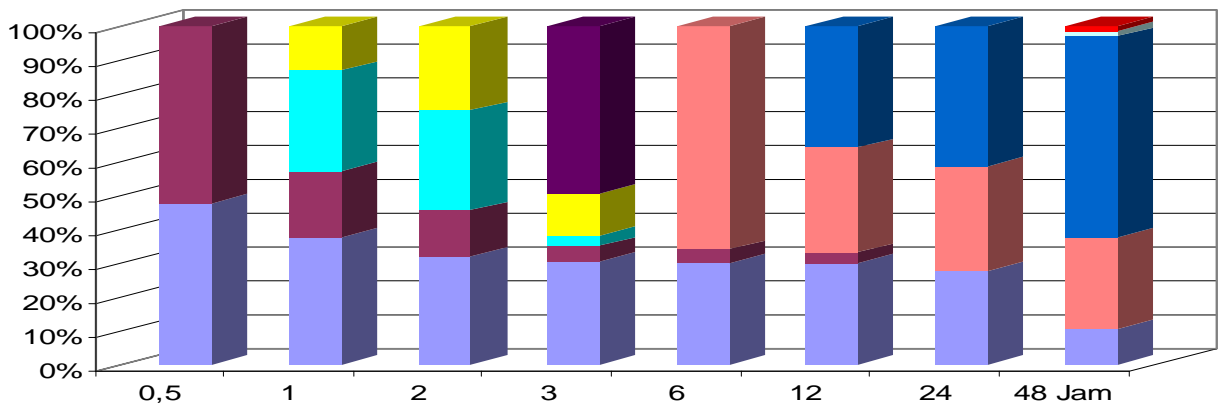

B

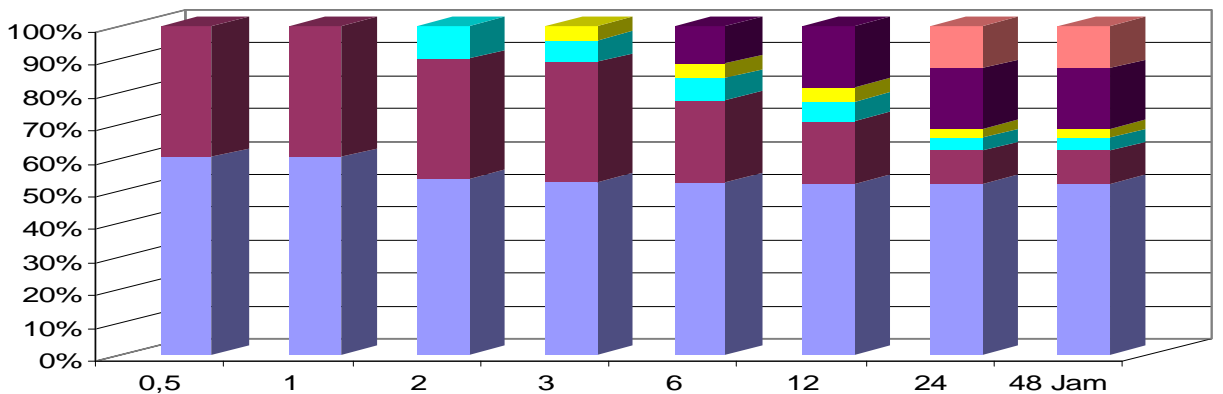

C

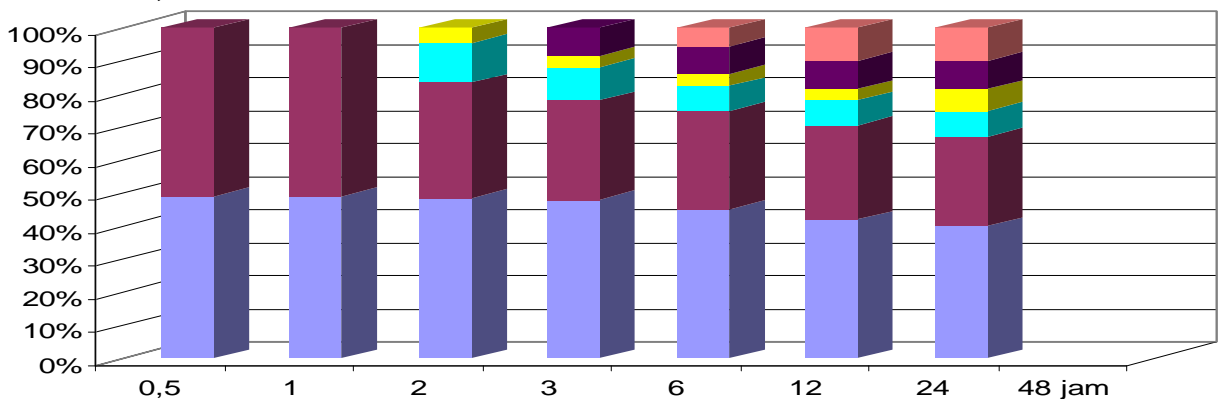

D

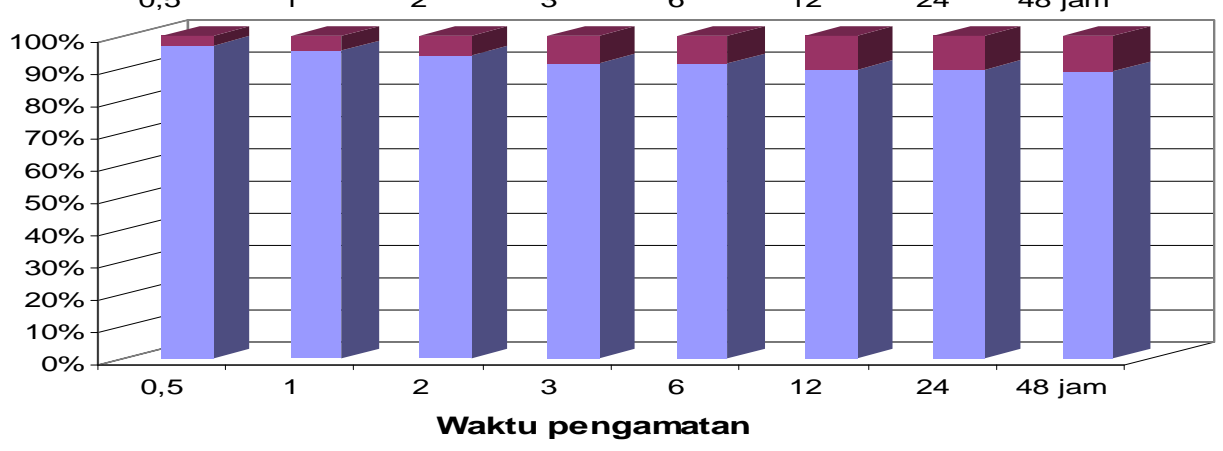

$\mathbf{E}$

$$
\begin{aligned}
& \text { Tidak Fertilisasi } \\
& \text { Pembelahan } 4 \text { Sel } \\
& \text { Blastula } \\
& \text { Pluteus }
\end{aligned}
$$

$$
\begin{array}{ll}
\text { Membran Fertilisasi } & \text { Pembelahan 2 Sel } \\
\text { Pembelahan 8 Sel } & \text { Hatching } \\
\text { Gastrula } & \text { Prisma }
\end{array}
$$

Gambar 1. Persentasi Tahapan Perkembangan Embrio dari Sel Telur pada Setiap Perlakuan : A (Kontrol), B (Ekstrak Metanolik), C (Fraksi Larut Etil asetat), D (Fraksi Larut Heksan), dan E (Fraksi Larut Kloroform) 


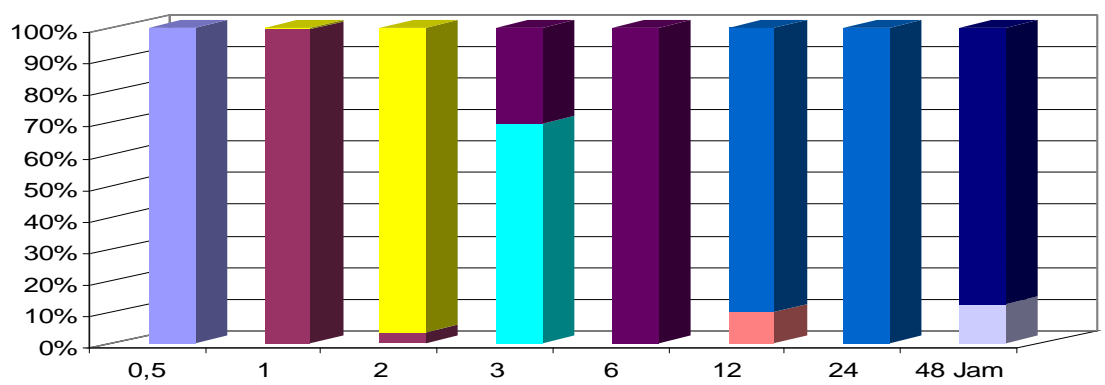

A

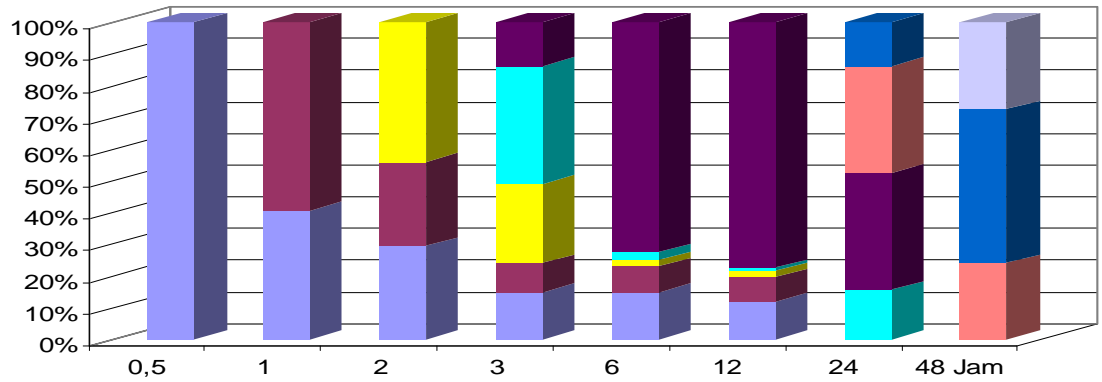

B

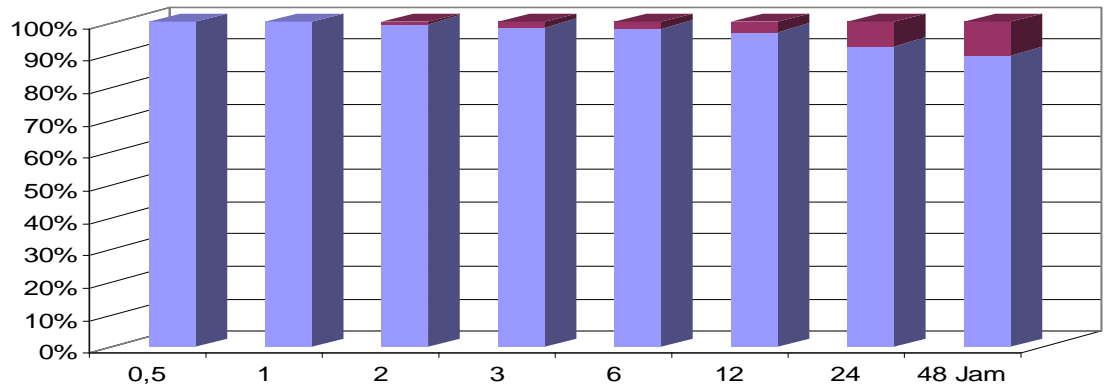

C

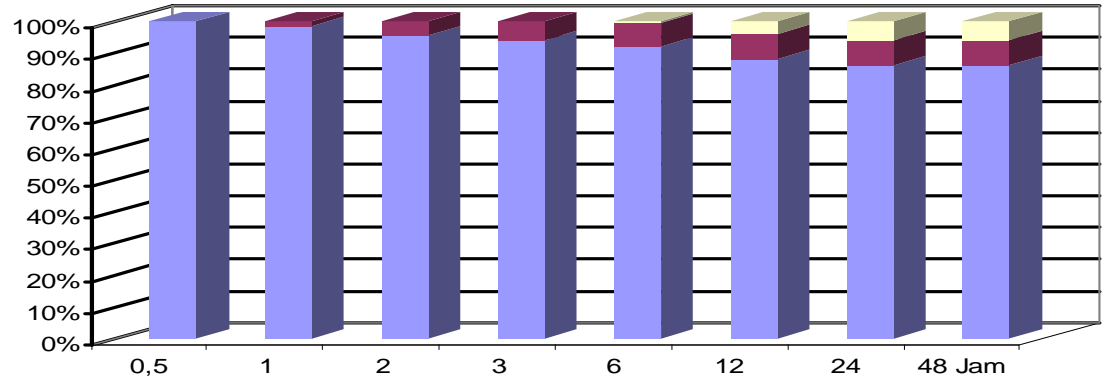

D

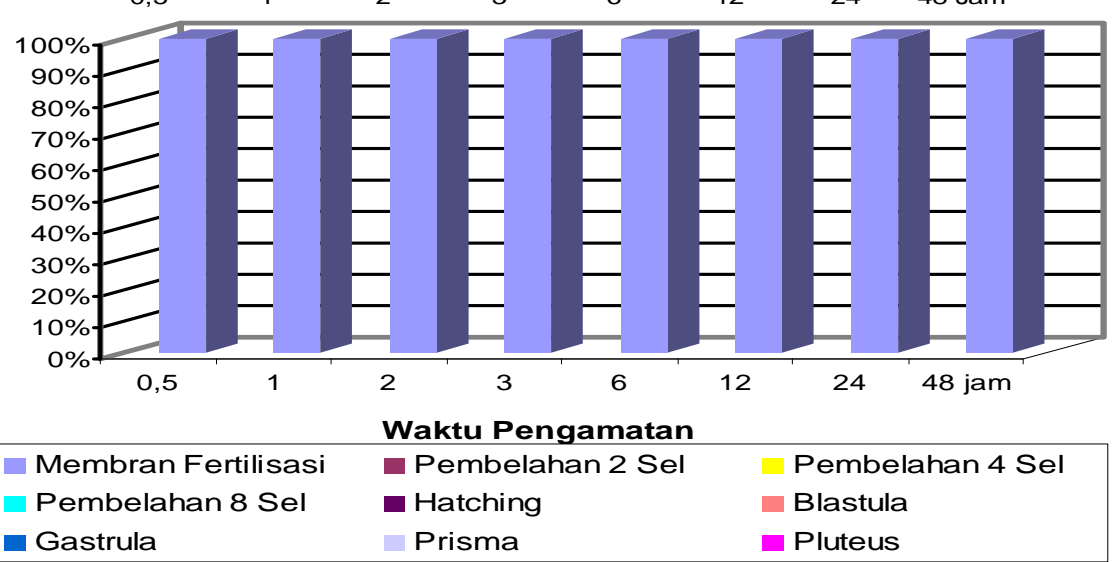

Gambar 2. Persentasi Tahapan Perkembangan Embrio Bulu Babi yang diberi Perlakuan : A(Kontrol), B(Ekstrak Metanolik), C(Fraksi Larut Etil asetat), D(Fraksi Larut Heksan), dan E(Fraksi Larut Kloroform) 


\section{KESIMPULAN DAN SARAN}

ari penelitian ini disimpulkan bahwa: ekstrak Bintang ular $O$. annulosa mengandung senyawa dengan aktivitas sitotoksik. Komponen aktif sitotoksik dari bintang ular O. Annulosa terdapat pada fraksi larut kloroform.

Adapun saran yang diajukan yaitu: perlu dilakukan pemurnian lebih lanjut terhadap fraksi larut kloroform O. Annulosa.

\section{DAFTAR PUSTAKA}

Faulkner, D.J. 1992. Biomedical Uses For Natural Marine Chemical. Oceanus, Spring. Dalam Jurnal Natural Product Chemistry. Hal $29-35$.

Faturoso E., W.H.Gerwick, O.T.Scafati. 2012. Hand Book of Marine Natural Products. Vol I. Springer.

Fusetani, N., K. Warabi,Y. Nogata, Y. Nakao dan S. Matsunaga. 1999. Koshikamide A, a new cytotoxic Linear Peptide Isolated from a Marine Sponge Theonella sp. Tetrahedron Letters 40 : 46874690

Grzimek, B. 1972. Animal Life Encyclopedia vol3: Mollusks and Echinoderms. Van Nostrard Reinhold Company Inc. New York. 541 hal.

Iwamoto, C, T. Yamada, Y. Ito, K. Minoura dan A. Numata. 2001. Cytotoxic Cytochalans from a Penicillium Species Separated From a Marine Algae. Tetra hedron 57, hal : 2997-3004

Nagasawa Y, H.Kato, H. Rotinsulu, R.E.P. Mangindaan, N.J. de Voogd and S. Tsukamoto, 2011. Spironaamidine, a New Spiroquinone-Containing Alka loid From The Marine Sponge Leucetta microraphis. Tetra hedron Letters 52. 5342-5344 p.

Nagasawa Y, H.R. Uboka, R.Yamanukochi, N. Horiuchi, T.
Ikeda, H. Kato, H.Rotinsulu, R.E.P.Mangindaan, K.Ukay, H.Kobayashi, M. Namikoshi, H. Hirota, H. Yokosawa and S. Tsukamoto. 2011. Isolation Salsolinol, a Tetrahydro isoqui noline Alkaloid, from the Marine Sponge Xestospongia of vansoesti as a Proteasome Inhibitor. Chem.Pharm Bull. 59(2) 287-290.

Przybytek, J.T. 1984. Solvent Guide. Second Edition. Budrick@ Jack son Laboratories, Inc. 153 hal.

Rahman, A, I. Choudhary dan W. Thomsen. 2001. Bioassay Techniques for Drug Develop ment. Harwood Academic Publis hers. Amsterdam. $223 \mathrm{Hal}$.

Shokita, S.A. Kakazu. Tanori dan Toma, 1991. Aquaculture in Tropical Areas. Yamaguchi Published By Midori Shobo co,Itd. Halaman 313-327.

Siswandono dan Soekardjo. 2000. Kimia Medisinal, edisi kedua. Airlangga University Press. Surabaya. 756 hal.

Yamanokuchi R, K.Imada, M. Miyazaki, H. Kato, T.Watanabe, M.. Fujimoro, Y.Saeki, S.Yoshinaga, $\mathrm{H}$. Terasawa, N. Iwasaki, $\mathrm{H}$. Rotinsulu, F. Losung, R.E.P. Mangindaan, M. Namikoshi, N. J. de Voogd, H. Yokosawa and S. Tsukamoto, 2012. Bioorganic \& Medicinal Chemistry 20. 4437-4442. 